\title{
New taxa and a checklist of Afrotropical Metriorrhynchini (Coleoptera: Lycidae), with a note on biogeography of the tribe
}

\author{
Новые таксоны и список афротропических Metriorrhynchini \\ (Coleoptera: Lycidae) с замечанием по биогеографии трибы
}

\author{
Sergey V. Kazantsev \\ C.В.Казанцев
}

Insect Centre, Donetskaya 13-326, Moscow 109651, Russia.

Инсект-центр, ул. Донецкая 13-326, Москва, 109651, Россия, e-mail: kazantss@mail.ru

KEY WORDS: Coleoptera, Lycidae, Metriorrhynchini, new genera, new species, taxonomy, Afrotropical zone.

КЛЮЧЕВЫЕ СЛОВА: Coleoptera, Lycidae, Metriorrhynchini, новые рода, новые виды, таксономия, афротропическая область.

ABSTRACT. Two new genera, Paracautires gen.n. and Spartoires gen.n., and six new species are described in Metriorrhynchini: Paracautires afra, Spartoires murzini, Tricautires tabounensis (W Africa), Xylobanus uluguriensis, $X$. solodovnikovi and X. usambaraensis (Uganda), spp.n. The following replacement names are proposed in Cautires Waterhouse, 1879 and Xylobanus Waterhouse, 1879: Cautires africanoides nom.n. pro C. africanus Kleine, 1930, nec C. africanus (Pic, 1928); C. afrikaans nom.n. pro C. natalensis Kleine, 1926, nec C. natalensis (Bourgeois, 1902); $C$. afrops nom.n. pro $C$. aethiops (Kleine, 1933), nec $C$. aethiops Kleine, 1930; C. bantu nom.n. pro C. irregularis Kleine, 1926, nec C. irregularis (Pic, 1926); C. blaps nom.n. pro $C$. aethiops (Kleine, 1933), nec $C$. aethiops Kleine, 1930; C. flavips nom.n. pro C. flavipennis Kleine, 1930, nec C. flavipennis (Pic, 1925); C. maculensis nom.n. pro C. maculatithorax Kleine, 1930, nec C. maculatithorax (Pic, 1924); C. nigerorum nom.n. pro $C$. africanus Dudkova et Bocak, 2010, nec $C$. africanus (Pic, 1928); C. reductocostatus nom.n. pro C. reductus (Pic, 1928), nec C. reductus Pic, 1922; C. richardi nom.n. pro C. kleinei Bocak et Bocakova, 1988: 85, nec C. kleinei Pic, 1926; C. triangulus nom.n. pro C. triangularis Kleine, 1930, nec C. triangularis (Kleine, 1930); Xylobanus mauricei nom.n. pro $X$. diversithorax Pic, 1952, nec $X$. diversithorax Pic, 1925. A checklist of Afrotropical Metriorrhynchini and a key to the genera, as well as a note on biogeography of the tribe are provided.

РЕЗЮМЕ. Описывается два новых рода, Paracautires gen.n. и Spartoires gen.n., и шесть новых видов краснокрылов из трибы Metriorrhynchini: Paracautires afra, Spartoires murzini, Tricautires tabounensis (из Западной Африки), Xylobanus uluguriensis, $X$. solodovnikovi и X. usambaraensis (из Уганды), spp.n. В родах Cautires Waterhouse, 1879 и
Xylobanus Waterhouse, 1879 предлагаются замещающие названия: Cautires africanoides nom.n. pro $C$. africanus Kleine, 1930, nec C. africanus (Pic, 1928); $C$. afrikaans nom.n. pro $C$. natalensis Kleine, 1926, nec $C$. natalensis (Bourgeois, 1902); C. afrops nom.n. pro $C$. aethiops (Kleine, 1933), nec C. aethiops Kleine, 1930; $C$. bantu nom.n. pro $C$. irregularis Kleine, 1926, nec $C$. irregularis (Pic, 1926); C. blaps nom.n. pro C. aethiops (Kleine, 1933), nec C. aethiops Kleine, 1930; C. flavips nom.n. pro C. flavipennis Kleine, 1930, nec C. flavipennis (Pic, 1925); C. maculensis nom.n. pro C. maculatithorax Kleine, 1930, nec C. maculatithorax (Pic, 1924); $C$. nigerorum nom.n. pro C. africanus Dudkova et Bocak, 2010, nec C. africanus (Pic, 1928); C. reductocostatus nom.n. pro C. reductus (Pic, 1928), nec C. reductus Pic, 1922; C. richardi nom.n. pro C. kleinei Bocak et Bocakova, 1988: 85, nec C. kleinei Pic, 1926; C. triangulus nom.n. pro $C$. triangularis Kleine, 1930, nec $C$. triangularis (Kleine, 1930); Xylobanus mauricei nom.n. pro X. diversithorax Pic, 1952, nec $X$. diversithorax Pic, 1925. Приводится список афротропических Metriorrhynchini и определительная таблица родов, а также замечание по биогеографии трибы.

\section{Introduction}

The tribe Metriorrhynchini in the Afrotropical zone contains more than two hundred species and is among the two, along with Lycini, most species-rich groups of Lycidae here. However, very few papers dealing with the afrotropical metriorrhynchines were published after the middle of the last century [only Kazantsev, 2006a, to be exact], at a time when the Oriental and Papuan representatives of the tribe were being studied rather intensively [e.g., Kazantsev, 2000, 2002, 2006b, 2007, 2010; Bocák, 2002; Dudkova \& Bocák, 2010, etc.]. Conclusions of the mentioned papers lead to certain nomenclatural changes in the African fauna as well; 
besides, quite a number of new metriorrhynchine taxa have been discovered in the material collected in the region recently. Descriptions of some of these new netwinged beetles, as well as taxonomic changes that were deemed necessary are presented below. Also included is a key to the afrotropical Metriorrhynchini genera.

The following acronyms are used in the paper: ICCM - Insect Center Collection, Moscow; IRSN Institut Royal de Sciences naturelles de Belgique, Bruxelles; ZMCU - Zoological Museum of Copenhagen University.

\section{Taxonomy}

\section{Paracautires Kazantsev gen.n.}

Type species: Paracautires afra Kazantsev sp.n.

DESCRIPTION. Male. Alate, flattened, elongate. Head transverse. Fastigium right-angled. Eyes relatively small, spherical. Labrum small, transverse, sclerotized, lying anteriad of epistoma, without median incision. Mandibles small, smoothly and strongly curved. Maxillary palps slender, 4-segmented, with ultimate palpomere pointed and glabrous at apex (Fig. 1). Labium with small quadrate prementum; palps 3-segmented, slender, with ultimate palpomere pointed and glabrous at apex. Antennal prominence conspicuous, antennal sockets separated by minute lamina. Antenna 11-segmented, moderately long, antennomeres 3-10 flabellate; antennomere 2 small, considerably shorter than antennomere 3; pubescence moderately long and erect (Fig. 2).

Pronotum transverse, moderately pentagonal, with anterior median carina and posterior median areole; sides broadly deflexed; posterior margin bisinuate, posterior angles acute; vestiture rather long and erect (Fig. 3). Prosternum very short, V-shaped. Thoracic spiracles elongate, with anterior hood, but not projecting beyond coxae. Mesoventrite transverse, not divided by median suture. Mesonotal scutellum elongate, parallel-sided, deeply incised at apex and leaving a noticeable notch. Elytra elongate, slightly widening and dehiscent distally, with four fully developed primary costae; interstices with one row of irregular cells, at base and at distal third with two rows of subquadrate cells; uniform pubescence relatively long and erect, denser along costae (Fig. 4).

Protrochantins considerably more prominent than mesotrochantins, mesotrochantins slender and very narrow. Procoxae transverse, mesocoxae elongate, metacoxae broadly separated. Legs relatively robust; trochanters elongate, but considerably shorter than femurs, subconical, connected to femora distally; femurs and tibiae flattened, tibiae (in inner margin) straight, tibial spurs short, hardly noticeable; tarsomeres 1-3 narrow, tarsomeres 1-2 without plantar pads, tarsomere 3 with apical plantar pad, tarsomere 4 bilobed; all claws simple, provided with a blunt tooth at base. Abdomen with 8 ventrites (visible sternites). Sternite 9 elongate, subtriangular, with spiculum gastrale ca. half of distal portion of sternite, acute at apex. Aedeagus with straight, widened distally median lobe; inner sac with a pair of bidentate spines; phallobase narrow, annuliform, with ventral incision (Figs 5-6).

Female. Unknown.

ETYMOLOGY. The name of the genus is derived from the Greek for "beside" and the genus name "Cautires". Gender masculine.

DIAGNOSIS. Paracautires gen.n. is readily differentiated from the somewhat similar Tricautires Kazantsev, 2006 by the developed third primary elytral costa (Fig. 4), long erect uniform elytral pubescence, narrow tarsomeres $1-3$ and absent plantar pads on tarsomeres 1-2. The new genus differs from Cautires by the pointed ultimate maxillary and labial palpomeres, long erect uniform elytral pubescence, narrow tarsomeres 1-3 and absent plantar pads on tarsomeres 1-2.

DISTRIBUTION. Equatorial Guinea (Bioko Is.), Cameroon.

\section{Paracautires afra Kazantsev sp.n.} Figs 1-6

MATERIAL: Holotype, $0^{7}$, Equatorial Guinea, Bioko (Fernando Poo), Mt. Santa Isabel, 1974, A. Petrov leg. (ICCM); paratypes: $3 \sigma^{7} \sigma^{7}$, Cameroon, Batanga, II-III.1950; $1 \sigma^{7}$, Cameroon, R.F. Makak, 31.I.1950 (ICCM).

DESCRIPTION. Male. Uniformly testaceous.

Head dorsally with conspicuous transverse impression, antennal sockets separated by minute lamina. Eyes small (separated medially above by about 4 times their radius). Ultimate maxillary palpomere small, elongate, tapering distally (Fig. 1). Antennae extending to elytral two thirds; from antennomere 3 flattened, flabellate, antennomere 3 about 10 times longer than antennomere 2 and subequal in length to antennomere 4; flabellae of antennomeres 3-11 considerably longer than antennomeres (Fig. 2); antennomeres 3-11 with relatively long erect pubescence.

Pronotum transverse, 1.5 times wider than long, slightly trapezoidal, with median carina in anterior third, narrow areole in posterior two thirds and traces of anterior lateral carinae, with conspicuous anterior and small acute posterior angles; anterior margin slightly triangularly produced forward (Fig. 3). Scutellum elongate, with deep distal incision, exceeding half scutellar length.

Elytra long, 3 times as long as wide humerally, slightly widening and dehiscent in distal half (Fig. 4).

Aedeagus with straight, relatively robust, ovally dilated distally median lobe (Figs 5-6).

Female. Unknown.

Length: $5.9-6.9 \mathrm{~mm}$. Width (humerally): $1.5-1.7 \mathrm{~mm}$.

ETYMOLOGY. The name of the new species is derived from the noun "Biafra", in accordance with the area of its distribution, by deletion of prefix "bi-".

DIAGNOSIS. P. afra sp.n. differs from other metriorrhynchine species from Africa by the generic characters.

\section{Spartoires Kazantsev gen.n.}

Type species: Spartoires murzini Kazantsev sp.n.

DESCRIPTION. Male. Alate, flattened, elongate. Head transverse. Fastigium almost right-angled, ca. 80 degrees. Eyes relatively small, spherical. Labrum transverse, sclerotized, lying anteriad of epistoma, with feeble median incision. Mandibles prominent, smoothly curved. Maxillary palps slender, 4-segmented, with ultimate palpomere almost parallel-sided, flattened and glabrous at apex (Fig. 7). Labium with relatively long prementum; palps 3-segmented, with ultimate palpomere flattened and glabrous at apex. Antennal prominence relatively inconspicuous, antennal sockets separated by minute lamina. Antenna 11-segmented, moderately long, antennomeres 3-10 flabellate; antennomere 2 small, considerably shorter than antennomere 3; pubescence short and decumbent (Fig. 8).

Pronotum moderately large, pentagonal, with median carina in anterior half; sides broadly deflexed; posterior margin bisinuate, posterior angles acute (Fig. 9). Prosternum very short, V-shaped. Thoracic spiracles elongate, hooded, not projecting beyond coxae. Mesoventrite transverse, not divided by median suture. Mesonotal scutellum subquadrate, noticeably incised at apex and leaving a notch. Elytra elon- 
gate, slightly widening distally, with four fully developed primary costae; interstices with one row of transverse cells, except portions at base and at distal fourth with two rows of quadrate cells; very short elytral pubescence limited to longitudinal and transverse costae.

Protrochantins and mesotrochantins slender and very narrow. Pro- and mesocoxae transverse; metacoxae separat-
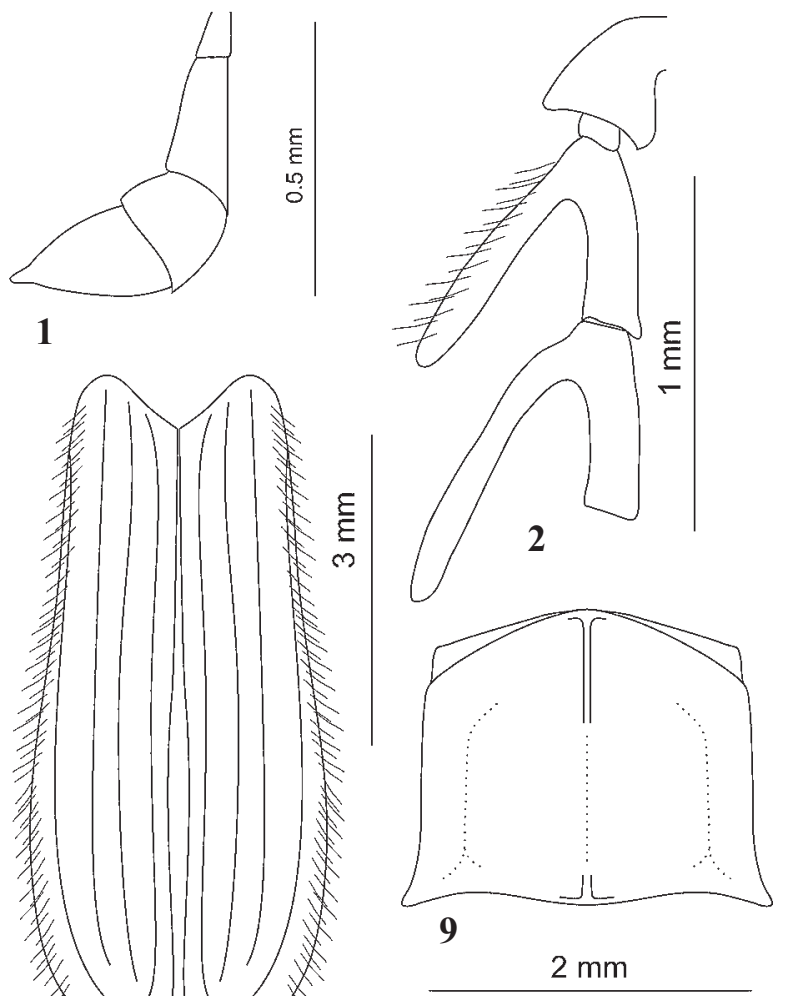

1

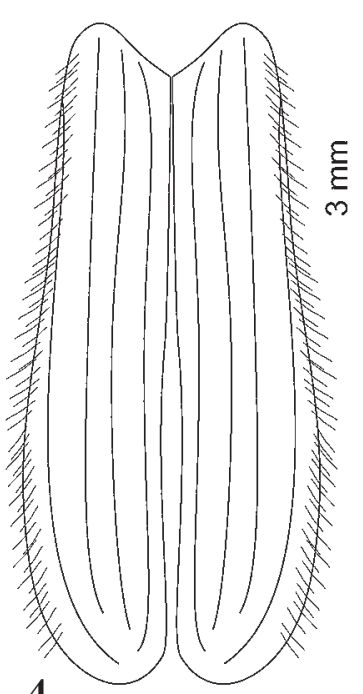

4
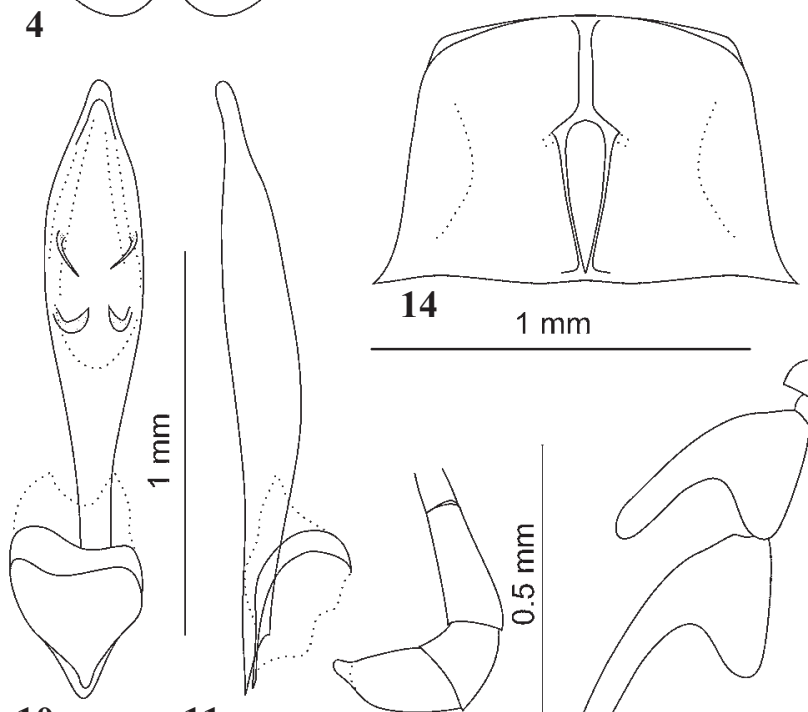

10

11
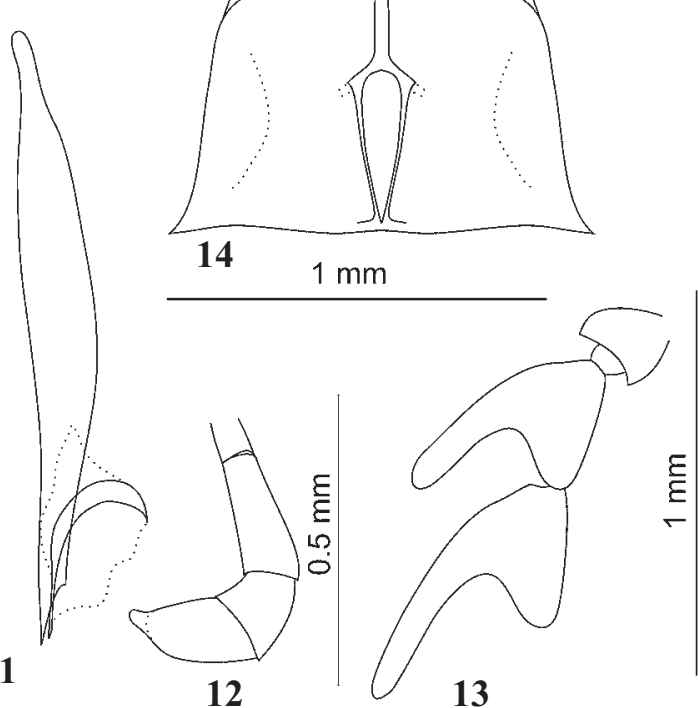

ed. Legs relatively robust; trochanters elongate, but considerably shorter than femurs, subconical, connected to femora distally; femurs and tibiae flattened, tibiae (in inner margin) straight, tibial spurs short, hardly noticeable; tarsomeres 1-4 with plantar pads, tarsomeres 3-4 widened; all claws simple. Abdomen with 8 ventrites (visible sternites). Sternite 9 elongate, subtriangular, with spiculum gastrale subequal in length
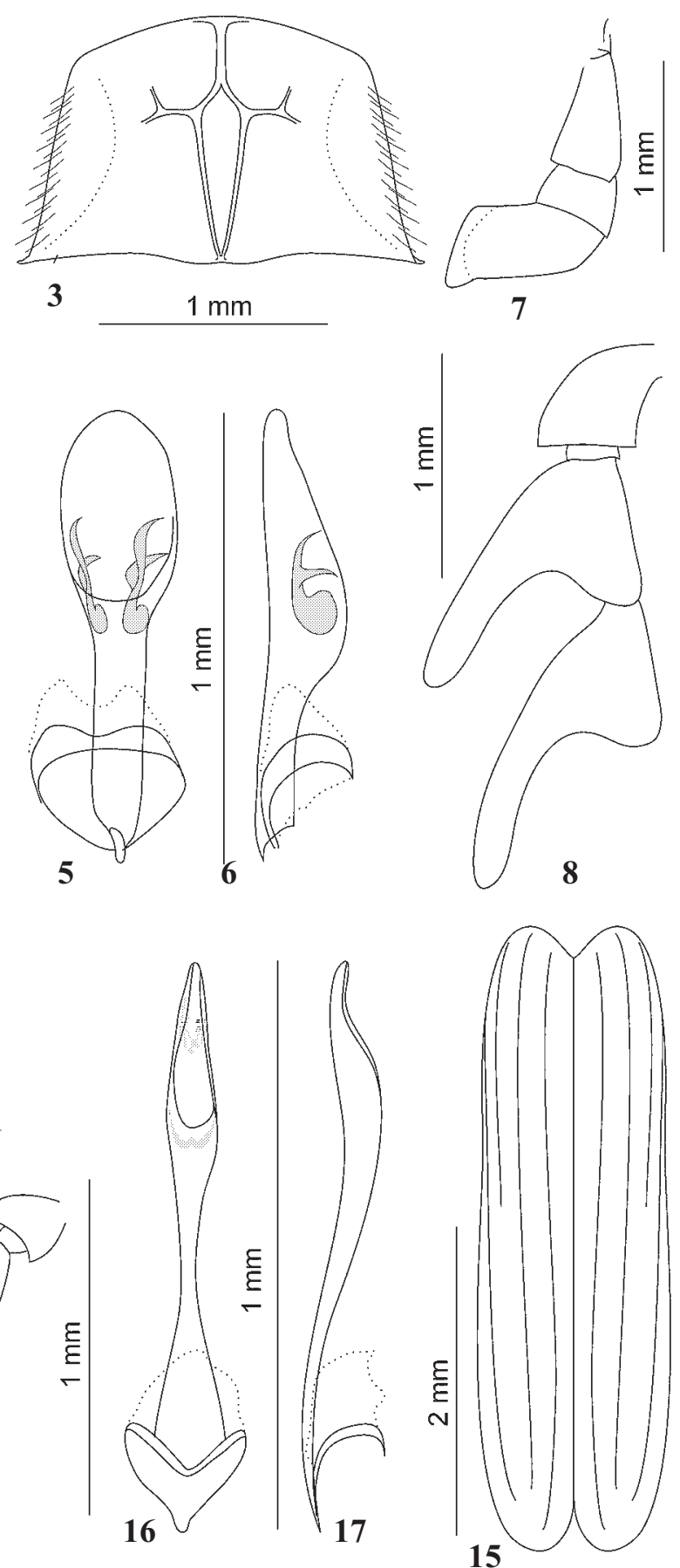

Figs 1-17. Details of Metriorrhynchini spp., holotypes males: 1-6 - Paracautires afra gen.n., sp.n.; 7-11 - Spartoires murzini gen.n., sp.n.; 12-17 - Tricautires tabounensis sp.n.; 1, 7, 12 - ultimate maxillary palpomere; 2, 8, 13 - antennomeres 1-4; 3, 9, 14 - pronotum; 4,15 - primary elytral costae; 5-6, 10-11, 16-17 - aedeagus.

Рис. 1-17. Детали строения Metriorrhynchini spр., голотипы, самцы: 1-6 - Paracautires afra gen.n., sp.n.; 7-11 - Spartoires murzini gen.n., sp.n.; 12-17 — Tricautires tabounensis sp.n.; 1, 7, 12 - вершинный челюстной щупик; 2, 8, 13 - антенномеры 1-4; 3, 9, 14 - переднеспинка; 4, 15 - первичные рёбра надкрыльев; 5-6, 10-11, 16-17 - эдеагус. 
to distal portion of sternite, acute at apex. Aedeagus with straight, tapering distally median lobe; inner sac with a pair of spines; phallobase narrow, annuliform, with ventral incision (Figs 10-11).

Female. Similar to male, but antennae less flabellate.

ETYMOLOGY. The name of the genus is a combination of "spartan", the Greek for "simple", and the genus name "Cautires", alluding to its simplified pronotal structure. Gender masculine.

DIAGNOSIS. Spartoires gen.n., being apparently related to Cautires Waterhouse, 1879, is readily differentiated from it by the pronotal structure without areoles (Fig. 1), which appears to be its apomorphy. The absent pronotal areoles are very seldom met in the Metriorrhynchini: in fact, apart from Spartoires gen.n., only Caenioxylobanus Pic, 1922, a Madagascan endemic, does not have any.

DISTRIBUTION. Congo Basin (Zaire and Congo).

\section{Spartoires murzini Kazantsev sp.n.}

Figs 7-11

MATERIAL: Holotype, $0^{7}$, Congo (Brazz.), Odzala Nat. Park, 10.II.1997, S. Murzin leg. (ICCM); paratypes: 2 우, same labe (ICCM); $1 \mathrm{O}^{\top}$, [Zaire], «Congo belge: Mayumbe, Kimongo, IX.1925, A. Collart» (IRSN).

DESCRIPTION. Male. Dark brown to black. Pedicel, antennomere 11 distally, pronotum, except at disk, and elytral proximal three fourths testaceous.

Head dorsally almost flat, antennal sockets separated by minute lamina. Eyes relatively small (separated medially above by about 2 times their radius). Ultimate maxillary palpomere elongate, almost parallel-sided, flattened and glabrous distally (Fig. 7). Antennae extending to elytral middle; from antennomere 3 flabellate, flabellae slightly exceeding length of antennomeres; antennomere 3 about 10 times longer than antennomere 2 and subequal in length to antennomere 4 (Fig. 8); antennomeres 3-11 with short decumbent pubescence.

Pronotum transverse, 1.2 times wider than long, with narrow median carina anteriorly and narrow shallow furrow posteriorly, almost straight sides, conspicuous anterior and small acute posterior angles; anterior margin triangularly produced forward (Fig. 9). Scutellum elongate, parallel-sided, triangularly emarginate at apex.

Elytra long (ca. 4 times as long as wide humerally).

Aedeagus with straight, relatively robust median lobe, with slightly bent distal portion (Fig. 10-11).

Female. Similar to male, but antennomeres 3-10 feebly flabellate.

Length: $8.8-10.0 \mathrm{~mm}$. Width (humerally): $2.2-2.6 \mathrm{~mm}$.

ETYMOLOGY. The new species is named after Dr. S. Murzin (Moscow), who collected most specimens of the type series.

DIAGNOSIS. S. murzini sp.n. is easily differentiated from other African metriorrhynchines by the generic characters.

\section{Tricautires tabounensis Kazantsev sp.n.} Figs $12-17$

MATERIAL: Holotype, $\sigma^{7}$, Afrique occ., Guinée, Forêt Tabouna, 21.IX.1982, S. Murzin leg. (ICCM); paratypes: $2 \sigma^{\top} \sigma^{\top}$, same label; $1 \Im^{7}$, same label, 3.VIII.1982; 1 ऽ, Afrique occ., Guinée, pr. Forecariah, Sikhourou primary forest, 18.IX.1984, S. Murzin leg. (ICCM); 1 +, [Zaire], Stanleyville, 9-13.XII.1929, A. Collart (ICCM) 1 \%, [Zaire], Congo belge: Libutu, Masua, 10.IX.1929, A. Collart (IRSN); 1 ○', [Zaire], Congo belge, Stanleyville, 13.VII.1929, A. Collart (IRSN)

DESCRIPTION. Male. Dark brown to black. Pedicel, antennomere 11 distally, pronotal sides, elytral proximal three fourths, trochanters and proximal third of femurs testaceous.
Head dorsally almost flat, antennal sockets separated by minute lamina; fastigium right-angled. Eyes relatively small (separated medially above by about 2.5 times their radius). Ultimate maxillary palpomere elongate, pointed and glabrous distally (Fig. 12). Antennae extending to elytral two thirds; from antennomere 3 flabellate, flabellae in antennomeres 4-10 considerably exceeding length of antennomeres; antennomere 3 about 10 times longer than antennomere 2 and subequal in length to antennomere 4 (Fig. 13); antennomeres 3-11 with short decumbent pubescence.

Pronotum transverse, ca. 1.5 times wider than long, with median carina anteriorly and narrow areole posteriorly, almost straight sides, noticeable anterior and small acute posterior angles; anterior margin produced forward (Fig. 14). Scutellum elongate, parallel-sided, triangularly emarginate at apex.

Elytra long (3.3 times as long as wide humerally), almost parallel-sided, with primary costa 3 extending to elytral middle (Fig. 15); interstices with double rows of elongate pentagonal or roundish cells. Pubescence along longitudinal and transverse costae, short and decumbent.

Aedeagus with slender, constricted distally and conspicuously bent median lobe (Figs 16-17).

Female. Similar to male, but antennomeres 3-10 less flabellate.

Length: 5.0-7.2 mm. Width (humerally): 1.1-1.8 mm.

ETYMOLOGY. The name of the new species is derived from the area where most specimens of the type series were collected.

DIAGNOSIS. T. tabounensis sp.n. is easily differentiated from $T$. isabelae Kazantsev, 2006, the second known species of the genus, by the black antennomeres 9 and 10 , bicoloured pronotum and longer third primary elytral costa (Fig. 15), extending to elytral middle.

\section{Xylobanus uluguriensis Kazantsev sp.n.} Figs 18-21

MATERIAL: Holotype, $\sigma^{7}$, Tanzania, Uluguri Mts., 14001600 m, VII.1975, N. Drozdov leg. (ICCM).

DESCRIPTION. Male. Dark brown to black. Head, antennomeres 1, 2 and 11, pronotum, scutellum, elytra at humeri, proand mesocoxae, trochanters, front femurs and knees testaceous.

Head with conspicuous transverse impression behind antennal prominence, antennal sockets separated by minute lamina. Eyes small (separated medially above by about 4 times their radius). Ultimate maxillary palpomere small, elongate, parallel-sided, obliquely truncate distally. Antennae extending to elytral two thirds; from antennomere 3 flattened, serrate, antennomere 3 about 5 times longer than antennomere 2 and 1.1 times shorter than antennomere 4 (Fig. 18); antennomeres 3-11 with short sub-erect pubescence.

Pronotum moderately transverse, 1.15 times wider than long, slightly trapezoidal, with median carina in anterior two fifths, narrow areole in posterior three fifths and traces of antero-lateral carinae, with conspicuous anterior and small acute posterior angles; anterior margin produced forward (Fig. 19). Scutellum elongate, with triangular distal incision.

Elytra long, 4.7 times as long as wide humerally, widening distally, with regular elongate cells in interstices between primary costae; short and decumbent pubescence present on longitudinal and transverse costae.

Legs long and slender, tibiae straight, plantar pads on tarsomeres 1 and 2 apical.

Paraproct (tergite 9) divided by complete median suture; spiculum gastrale ca. 2.5 times shorter than sternite proper, narrow, parallel-sided, rounded proximally. Aedeagus with slightly curved, moderately robust, dilated distally median lobe (Figs 20-21). 
Female. Unknown.

Length: $6.0 \mathrm{~mm}$. Width (humerally): $1.1 \mathrm{~mm}$.

ETYMOLOGY. The name of the new species is derived from the Uluguri Mountains in Tanzania, where the unique type specimen was collected.

DIAGNOSIS. $X$. uluguriensis sp.n. differs from other afrotropical members of the genus by a combination of strongly serrate antennomeres 3-10 (Fig. 18), absent antero-lateral pronotal areolae (Fig. 19), long and widening distally elytra with elongate cells in interstices and somewhat curved median lobe of the aedeagus (Figs 20-21).

\section{Xylobanus solodovnikovi Kazantsev sp.n.}

Figs 22-25

MATERIAL: Holotype, $0^{\top}$, Tanzania, Uzungwe Mts., Mwanihana Forest above Senje, 1000 m, 1.VIII.1981, M. Stoltze \& N. Scharff leg. (ZMCU); paratypes: $2 O^{7} O^{7}$, same label (ZMCU and ICCM).

DESCRIPTION. Male. Dark brown to black. Head, maxillary palpomeres 1 and 2, antennomeres 1 and 2, pronotum, scutellum, elytra at anterior fourth, pro- and mesocoxae, trochanters, front and middle femurs testaceous.

Head with noticeable impression behind antennal prominence, antennal sockets separated by minute lamina. Eyes
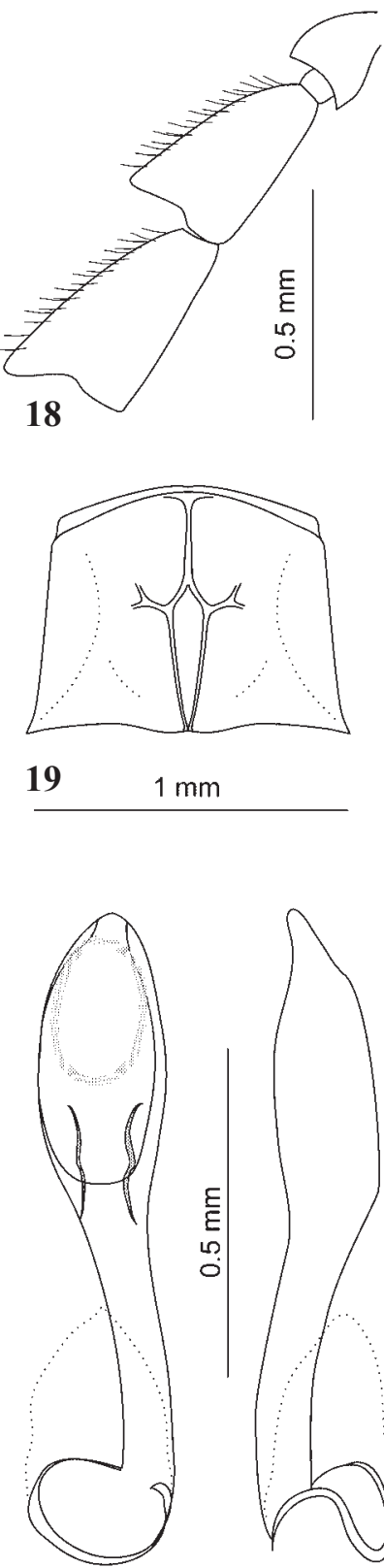

20

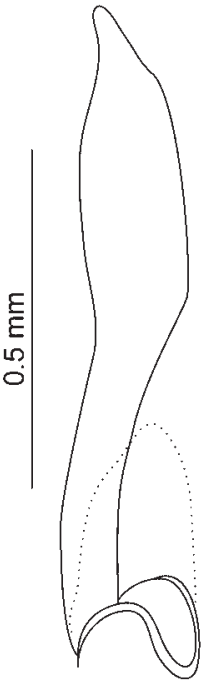

21
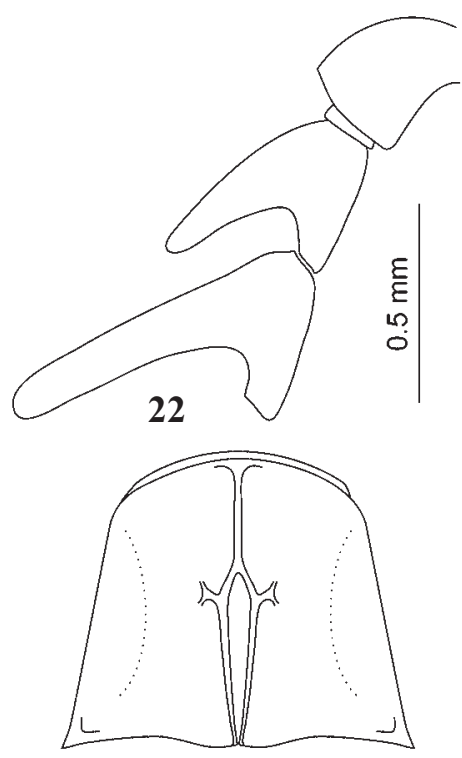

23

$1 \mathrm{~mm}$

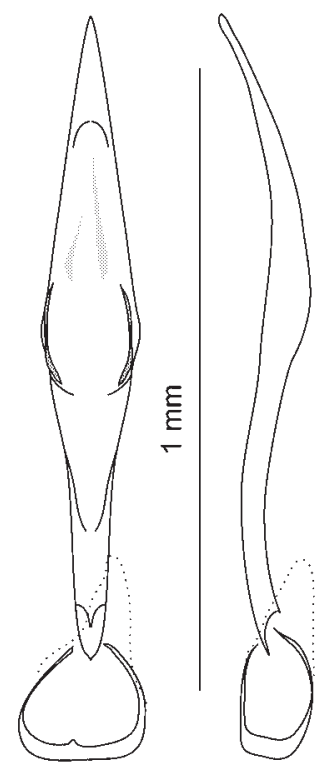

24

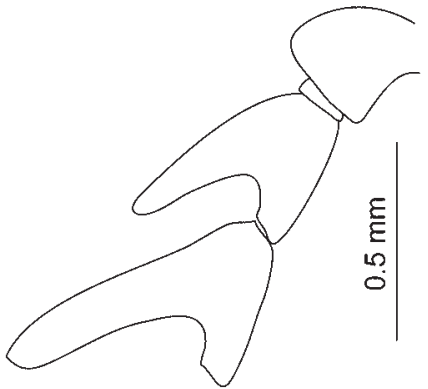

26
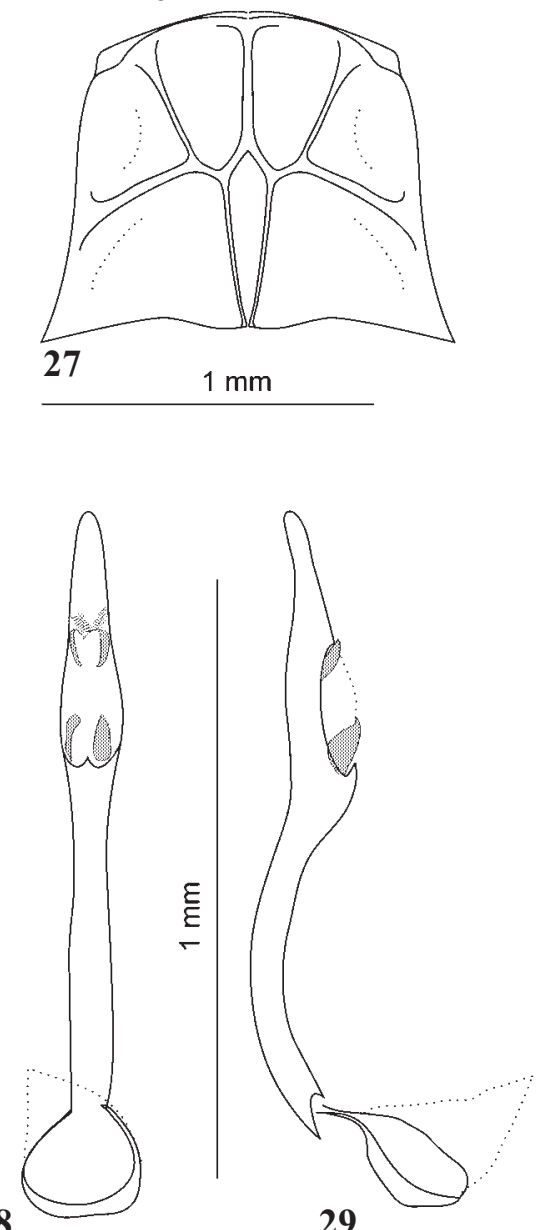

29

Figs 18-29. Details of Xylobanus spp., holotypes males: 18-21 - X. uluguriensis sp.n.; 22-25 - X. solodovnikovi sp.n.; 26-29 X. usambaraensis sp.n.; 18, 22, 26 - antennomeres 1-4; 19, 23, 27 -pronotum; 20-21, 24-25, 28-29 - aedeagus.

Рис. 18-29. Детали строения Xylobanus spp., голотипы, самцы: 18-21 - X. uluguriensis sp.n.; 22-25 - X. solodovnikovi sp.n.; 26-29 - X. usambaraensis sp.n.; 18, 22, 26 - антенномеры 1-4; 19, 23, 27 - переднеспинка; 20-21, 24-25, 28-29 - эдеагус. 
small (separated medially above by about 3 times their radius). Ultimate maxillary palpomere elongate, widened distally, obliquely convex at distal margin. Antennae extending to elytral two thirds; from antennomere 3 flattened, flabellate, antennomere 3 about 10 times longer than antennomere 2 and subequal in length to antennomere 4 (Fig. 22); antennomeres 3-11 with short sub-erect pubescence.

Pronotum elongate, ca. 1.1 times longer than wide at base, slightly narrowing anteriorly, with median carina in anterior half, narrow areole in posterior half and traces of antero-lateral carinae, with inconspicuous anterior and small acute posterior angles; anterior margin semicircularly produced forward (Fig. 23). Scutellum elongate, parallel-sided, with triangular distal incision.

Elytra long, ca. 4.1 times as long as wide humerally, widening distally, with regular, slightly transverse cells in interstices between primary costae; short and decumbent pubescence present on longitudinal and transverse costae.

Legs relatively short, slender, tibiae straight.

Paraproct (tergite 9) divided by complete median suture; spiculum gastrale short and broad. Aedeagus with straight, narrow, pointed distally median lobe (Figs 24-25).

Female. Unknown.

Length: 5.8-6.5 mm. Width (humerally): $1.2-1.3 \mathrm{~mm}$.

ETYMOLOGY. The new species is named after Dr. A. Solodovnikov (Copenhagen), through whose courtesy I was able to study the ample afrotropical material of the Zoological Museum of Copenhagen University.

DIAGNOSIS. $X$. solodovnikovi sp.n., although somewhat resembling $X$. fuscatus Bourgeois, 1900, differs by coloration (testaceous antennomeres 1 and 2, uniformly testaceous pronotum, predominantly black elytra, testaceous front and middle femurs), widening distally elytra and straight, narrow and pointed distally median lobe of the aedeagus (Figs 24-25).

\section{Xylobanus usambaraensis Kazantsev sp.n.} Figs 26-29

MATERIAL: Holotype, $\sigma^{7}$, Tanzania, East Usambara, Amani, 1000 m, 28.I.1977, H. Enghoff, O. Lomholdt, O. Martin leg. (ZMCU); paratypes: $1 \sigma^{7}$, same label, 30.I.1977 (ICCM); 1 ㅇ, Tanzania, East Usambara, Amani, Monga, 1000 m, 6.II.1977, H. Enghoff, O Lomholdt, O. Martin leg. (ICCM); 1 \%, Tanzania, Usambara Mts. Amani, 1000 m, 5.VIII.1979, M. Stoltze leg. (ZMCU); 1 \%, Tanzania, Usambara Mts., Amani, 1000 m, 15.VII.1980, M. Stoltze \& N Scharff leg. (ZMCU).

DESCRIPTION. Male. Dark brown to black. Head, antennomere 2 , maxillary palpomeres $1-3$, pronotum, except at disk posteriorly, scutellum, metaventral processus between mesocoxae, proximal half of elytra, front trochanters and front femurs proximally testaceous.

Head with noticeable transverse impression behind antennal prominence, antennal sockets separated by minute lamina. Eyes small (separated medially above by about 3 times their radius). Ultimate maxillary palpomere small, elongate, widening and obliquely truncate distally. Antennae extending to elytral three fifths; from antennomere 3 flattened, flabellate, antennomere 3 about 5 times longer than antennomere 2 and subequal in length to antennomere 4 (Fig. 26); antennomeres 3-11 with short sub-erect pubescence.

Pronotum subquadrate, trapezoidal, with median carina in anterior half, narrow areole in posterior half and developed antero-lateral and lateral carinae, with conspicuous anterior and prominent acute posterior angles; anterior margin semicircularly produced forward (Fig. 27). Scutellum square, with conspicuous triangular distal incision.
Elytra long, 4.2 times as long as wide humerally, almost parallel-sided, with regular elongate or quadrate cells in interstices between primary costae; short and decumbent pubescence along longitudinal and transverse costae.

Legs relatively short, slender, tibiae straight.

Paraproct divided by complete median suture; spiculum gastrale about as long as sternite proper, relatively broad, parallel-sided, rounded proximally. Aedeagus with straight narrow median lobe (Figs 28-29).

Female. Similar to male, but antennae only serrate.

Length: 5.9-7.0 mm. Width (humerally): 1.2-1.4 mm.

ETYMOLOGY. The name of the new species is derived from the Uluguri Mountains in Tanzania, where the type series was collected.

DIAGNOSIS. $X$. usambaraensis sp.n. appears to be related to $X$. difficilis Kleine, 1927 , differing by a combination of coloration, flabellate antennomeres 3-10 (Fig. 26), subquadrate cells in elytral interstices and straight narrow median lobe of the aedeagus (Figs 28-29).

Following the study of the types of the genera Cladophorus Guérin-Méneville, 1830 and Procautires Kleine, 1925, it became apparent that they are absent east of the Wallace line [Bocák, 2002] and all records thereof in the Oriental zone and Africa should be attributed to Cautires. This entails the emergence of a number of cases of homonymy. Curiously, both Kleine and Pic, authors of the majority of the afrotropical metriorrhynchines [see references below], repeatedly noted that they find no difference between Cladophorus and Cautires, nevertheless continuing to add afrotropical species to both genera. The establishment of synonymy of Bulenides Waterhouse, 1879 and Cautires [Dudkova \& Bocák, 2010] results in another homonymy. The existing younger homonyms among the afrotropical taxa are proposed to be replaced by the following new names:

Cautires africanoides nom.n. pro Cautires africanus Kleine, 1930: 8, nec Cautires africanus (Pic, 1928): 112 (Procautires).

Cautires afrikaans nom.n. pro Cautires natalensis Kleine, 1926: 138, nec Cautires natalensis (Bourgeois, 1902): 744 (Cladophorus).

Cautires afrops nom.n. pro Cautires aethiops (Kleine, 1933): 5 (Cladophorus), nec Cautires aethiops Kleine, 1930: 10.

Cautires bantu nom.n. pro Cautires irregularis Kleine, 1926: 133, nec Cautires irregularis (Pic, 1926): 199 (Cladophorus).

Cautires blaps nom.n. pro Cautires aethiops (Kleine, 1933): 9 (Procautires), nec Cautires aethiops Kleine, 1930: 10.

Cautires flavips nom.n. pro Cautires flavipennis Kleine, 1930: 7, nec Cautires flavipennis (Pic, 1925): 5 (Cladophorus). Cautires maculensis nom.n. pro Cautires maculatithorax Kleine, 1930: 7, nec Cautires maculatithorax (Pic, 1924): 163 (Cladophorus).

Cautires nigerorum nom.n. pro Cautires africanus Dudkova et Bocák, 2010: 46, nec Cautires africanus (Pic, 1928): 112 (Procautires).

Cautires reductocostatus nom.n. pro Cautires reductus (Pic, 1928): 199 (Cladophorus), nec Cautires reductus Pic, 1922: 19.

Cautires richardi nom.n. pro Cautires kleinei Bocák et Bocáková, 1988: 85, nec Cautires kleinei Pic, 1926: 4.

Cautires triangulus nom.n. pro Cautires triangularis Kleine, 1930: 6, nec Cautires triangularis (Kleine, 1930): 351 (Bule- 
nides). Dudkova \& Bocák [2010] proposed a new replacement name for Cautires triangularis Kleine, 1930: 6, from Zaire, alleging that this taxon is a younger secondary homonym of Cautires reticulatus; however, these two names are different and, according to provisions of the ICZN, do not make homonymy - hence, the latter name replacement is invalid.

Xylobanus mauricei nom.n. pro Xylobanus diversithorax Pic, 1953: 4, nec Xylobanus diversithorax Pic, 1925: 5.

\section{Biogeography}

The tribe Metriorrhynchini is distributed in almost all tropical or semi-tropical regions of the Eastern Hemisphere, at the same time being absent in the Neotropics (Map 1), and in this respect is unique among the netwinged beetles. The metriorrhynchines make one of the most noticeable groups of Lycidae in Afrotropical, Oriental, Papuan and Australian zones, but, being relatively well represented in West Australia and Tasmania, have only one species in New Zealand. The tribe does have a limited number of taxa in the southeastern Palaearctic [Bocáková \& Bocák, 2007], but not a single species in the Nearctic [Miller, 2002].

The occurrence of the tribe in New Zealand and "Oceania" (Vanikuru, to the southeast of the Solomon Islands, being its easternmost record [Bourgeois, 1897; Kleine, 1933a]) does not exclude the possibility of its across the water dispersal at least to some areas of its distribution. The only New Zealand lycid species, which belongs to a widespread metriorrhynchine genus, for instance, seems to have been introduced across the water, well after the nearly complete submergence of the archipelago that must have obliterated its archaic lycid fauna. The same may be surmised of the two species registered on the volcanic island of Vanikuru.
However, such kind of expansion appears to be exceptional, as these lycids have not been recorded east or south of Vanikuru, in the direction of trades, and only one species has made it to New Zealand.

Given the continent drift theory is true, the emergence of metriorrhynchines should occur after the Pangaea split, because members of the lineage are absent or represent relatively few new-comers in fragments of former Lavrasia (e.g., in East Asia). On the other hand, their emergence should occur prior to the supercontinent Gondwana breakup, as metriorrhynchines occur on both blocs that emerged after the first Gondwanaland split, i.e., both on the South America/Africa bloc and the Madagascar/India/New Guinea/Australia/New Zealand/Antarctica bloc. In this respect the tribe should be at least ca. 200 (150, according to other studies) million years old.

The absence of the tribe in South America may be explained by its origin on the land mass of the future second bloc, presumably on or near the current Papuan zone, where diversity of the genus-group taxa is the highest, with its members crossing the future break-up line shortly before the Gondwana break-up and not expanding deep into the South America/Africa bloc prior to the split of the latter. Notably, the Metriorrhynchini are currently present on all fragments of the afore-mentioned second Gondwanaland bloc (except, quite expectedly, Antarctica).

The distribution pattern of Metriorrhynchini has another remarkable feature: they are the only lycid tribe registered in the Madagascan subregion (on Madagascar and Mauritius), while the adjacent Afrotropical subregion is fairly rich in net-winged beetles. There occur Lycini, Platerotini, Dexorini, Dictyopterini, Slipinskiini, Calochromini, representing almost the whole range of the higher-level taxa (the subfamilial arrange-

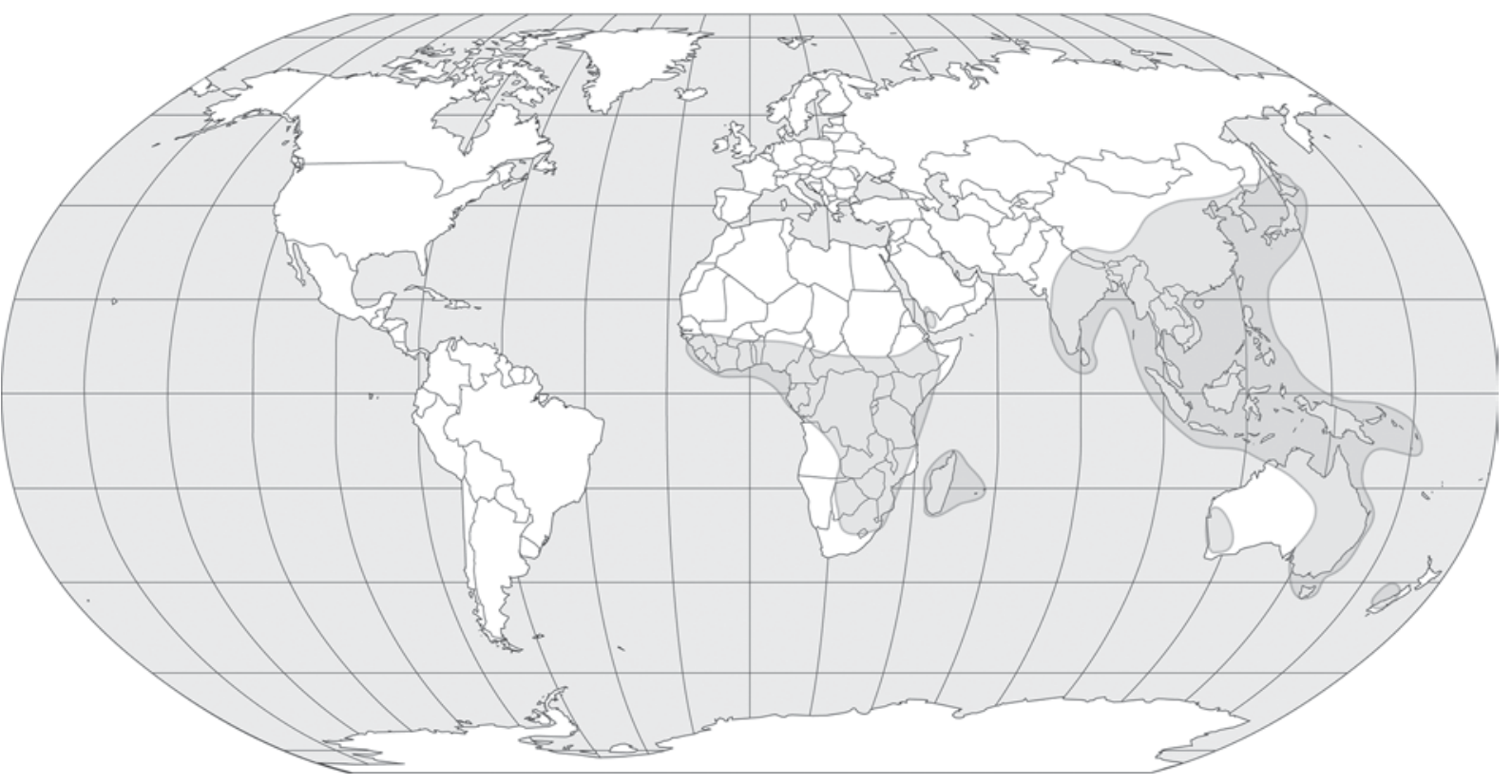

Map 1. World distribution of Metriorrhynchini.

Карта 1. Ареал трибы Metriorrhynchini. 
ment of Lycidae is still unclear - the available classifications are very contradictory [a paper addressing the problem in preparation]).

In the Afrotropical zone, currently known are 223 metriorrhynchine species distributed among six genera, Cautires Waterhouse, 1879 (168 species), Xylobanus Waterhouse, 1879 (46 species), Caenioxylobanus Pic, 1922 (5 species), Tricautires Kazantsev, 2006 (2 species), Paracautires gen.n. (1 species) and Spartoires gen.n. (1 species). Four genera, Caenioxylobanus, Tricautires, Paracautires gen.n. and Spartoires gen.n., are endemic for the zone. The Madagascan fauna lists three genera, Cautires, Xylobanus and Caenioxylobanus, one of which, Caenioxylobanus, is endemic for Madagascar.

\section{A key to the Afrotropical Metriorrhynchini genera}

1. Pronotum without areoles (e.g., Fig. 9) ... 2

- Pronotum at least with median areola posteriorly, often with additional antero-lateral areoles (e.g., Figs 3, 14, 27) .... 3

2. Pronotum with complete median longitudinal carina. Elytra with one row of cells between primary costae . Caenioxylobanus

- Pronotum with median carina in anterior half (Fig. 9). Elytra with two rows of cells between primary costae .. Spartoires gen.n.

3. Elytra with one row of cells between primary costae ....... Xylobanus

Elytra with two rows of cells between primary costae ..... 4

4. Maxillary and labial palps distally pointed and glabrous (Figs 1, 12) ....

- Maxillary and labial palps distally widened and pubescent Cautires

5. Third elytral costa not reduced (Fig. 4). Elytral pubescence long, erect and uniform. Tarsomeres 1-3 narrow, plantar pads on tarsomeres 1-2 absent ..... Paracautires gen.n.

- Third elytral costa greatly reduced (Fig. 15). Short and decumbent elytral pubescence present only on costae. Tarsomeres widened, plantar pads on tarsomeres 1-2 present Tricautires

\section{A list of Afrotropical Metriorrhynchini \\ tribe METRIORRHYNCHINI Kleine, 1926}

type genus: Metriorrhynchus Gemminger et Harold, 1869

Genus Caenioxylobanus Pic, 1922: 13

type species Caenioxylobanus ater Pic, 1922 ater Pic, 1922: 13. Madagascar.

bicoloricollis Pic, 1950:15. Madagascar. diversicollis Pic, 1922: 13 Madagascar. goudoti Bourgeois, 1908: 502 (Xylobanus). Madagascar. subdilatatus Pic, 1950:15. Madagascar.

Genus Cautires Waterhouse, 1879: 36

type species Lycus excellens Waterhouse, 1878

= Bulenides Waterhouse, 1879: 34

type species Lycus obsoletus Waterhouse, 1878 aethiops Kleine, 1930: 10. Zaire.

africanoides Kazantsev, 2012, nom.n. Zaire.

= africanus Kleine, 1930: 8 (homonym) africanus Pic, 1928: 112 (Procautires). Cameroon. afrikaans Kazantsev, 2012, nom.n. S Africa (Natal).

= natalensis Kleine, 1926: 138 (homonym) afrops Kazantsev, 2012, nom.n. E Africa (“Tanganyika”). = aethiops Kleine, 1933: 5 (Cladophorus) (homonym) angulatus Klug, 1833: 156 (Dictyoptera). Madagascar.

= grandipennis Fairmaire, 1889: viii angulicollis Pic, 1922: 20. Madagascar. annulipes Pic, 1933: 111 (Cladophorus). Zaire. anormalis Pic, 1928: 53 (Cladophorus). Uganda. apicalis Kleine, 1926: 131. W Africa ("Goldkueste"). atricollis Pic, 1922: 7. Zaire. atrimembris Pic, 1931: 261. Zaire. atrocarinatus Pic, 1953: 4. Madagascar. baillyi Fairmaire, 1880: 331. Madagascar. bambesianus Kleine, 1940: 253 (Procautires). Zaire. bantu Kazantsev, 2012, nom.n. Cameroon. = irregularis Kleine, 1926: 133 (homonym) biafrensis Bourgeois, 1905: 191. W Africa ("Spanish Guinea"). binotatus Pic, 1922: 7. Africa.

blaps Kazantsev, 2012, nom.n. Uganda. = aethiops Kleine, 1933: 9 (Procautires) (homonym) bolivari Bourgeois, 1905: 192. W Africa ("Spanish Guinea"). bosanganus Pic, 1933: 111. Zaire. bourgeoisi Fairmaire, 1901: 175. Madagascar. brazzai Pic, 1931: 106. Zaire. brevenotatus Pic, 1922: 19. Madagascar.

burgeoni Pic, 1933: 111. Zaire. Described as a variation of $C$. dilucidus Kleine, 1926.

calidus Harold, 1879: 106 (Caenia). Mozambique ("Dondo"). carnoti Pic, 1922: 19. Madagascar. caroli Pic, 1925: 185. E Africa.

cautiroides Kleine, 1933: 6 (Cladophorus). S Africa.

chariensis Pic, 1931: 107. The Central African Republic ("Fort Sibut").

chatanayi Pic, 1922: 20. Madagascar. circumcinctus Bourgeois, 1902: 747. Madagascar. claricollis Pic, 1953: 4. Madagascar. coarcticollis Bourgeois, 1910: 111 (Cladophorus). E Africa. concoloripennis Pic, 1933: 111. Zaire. congonus Kleine, 1930: 4. Zaire. conicicollis Pic, 1922: 20. Madagascar. conradti Kleine, 1926: 132. Cameroon. constans Kleine, 1930: 8. Zaire.

coquereli Fairmaire, 1869: 227 (Caenia). Madagascar. cordicollis Pic, 1931: 378 (Cladophorus). Uganda. costulatus Kleine, 1930: 5. Zaire. curtenotatus Pic, 1924: 163 (Cladophorus). Bioko Is. (Fernando-Poo).

curticornis Pic, 1928 : 53 (Cladophorus). E Africa (Eritrea). dalmani Bourgeois, 1910: 112. E Africa (Meru). dichrocerus Bourgeois, 1889: 241. W Africa. dilucidus Kleine, 1926: 132. Zaire. dimidius Kleine, 1926: 143. S Africa (Natal). discoidalis Kleine, 1926: 135. Uganda. discolor Kleine, 1926: 140. Zimbabwe. discors Kleine, 1926: 142. Zaire, Uganda. disjunctus Kleine, 1926: 137. Zaire, Uganda. diversesculptus Pic, 1922: 18. Cameroon. diversipes Pic, 1931: 107. Cameroon. diversithorax Pic, 1922: 18. Gabon. dohrni Fairmaire, 1869: 227. Madagascar. dolens Bourgeois, 1902: 747. Madagascar. dondonensis Harold, 1879: 105 (Caenia). W Africa. dubiosus Kleine, 1933: 6 (Cladophorus). Uganda. elongatissimus Kleine, 1935: 426. Central Africa ("Kaimosi"). exsertus Kleine, 1926: 142. Angola, Sierra Leone. fairmairei Bourgeois, 1902: 746. Madagascar favosus Gerstaecker, 1871: 56 (Cladophorus). E Africa. Syn- 
onymy of C. basicornis Fairmaire, 1887 was established by Bourgeois [1910], but overlooked by Kleine [1933a]. = basicornis Fairmaire, 1887: 155 (Eros)

feai Pic, 1924: 163 (Cladophorus). Bioko Is. (Fernando-Poo). flabellatus Pic, 1932: 23 (Procautires). Africa.

flavipennis Pic, 1925: 5 (Cladophorus). Rwanda (Birunga). flavips Kazantsev, 2012, nom.n. Zaire.

= flavipennis Kleine, 1930: 7 (homonym)

flavofemoralis Kleine, 1930: 10. Zaire.

flavomarginatus Kleine, 1942: 6. Rwanda.

fuscopubens Pic, 1922: 20. Madagascar.

gestroi Pic, 1924: 163 (Cladophorus). Bioko Is. (Fernando-Poo). gorhami Pic, 1922: 19. Madagascar.

gowdeyi Kleine, 1926: 131. Uganda.

gracilis Kleine, 1930: 9. Zaire.

granulosus Pic, 1922: 20. Madagascar.

holomelas Fairmaire, 1884: 229. Madagascar.

hulstaerti Kleine, 1935: 429. Zaire.

impressicollis Kleine, 1926: 140. E Africa (Usambara).

inaequalis Pic, 1928: 53 (Cladophorus). Cameroon.

inapicalis Pic, 1922: 18 Cameroon.

inflatellus Bourgeois, 1889: 243. W Africa (“Assinie”).

ingeniculatus Pic, 1922: 18. Gabon.

irregularis Pic, 1926: 199 (Cladophorus). Bioko Is. (Fernando-Poo).

jokoensis Pic, 1931: 107. Cameroon.

kilimanus Bourgeois, 1910. E Africa (Kilimanjaro).

klugi Fairmaire, 1869: 226. Madagascar, Maurutius.

lamellatus Kleine, 1930: 7. Zaire.

lateniger Pic, 1922: 8. E Africa (“Tanganyika").

latithorax Bourgeois, 1889: 244. Cameroon.

leonensis Pic, 1928: 53 (Cladophorus). Sierra Leone.

longithorax Kleine, 1926: 140. Cameroon.

lyciformis Pic, 1922: 7. E Africa.

macer Bourgeois, 1889: 242. Cameroon.

maculatithorax Pic, 1924: 163 (Cladophorus). Bioko Is. (Fernando-Poo).

maculensis Kazantsev, 2012, nom.n. Zaire, Rwanda.

= maculatithorax Kleine, 1930: 7 (homonym)

maculicornis Bourgeois, 1910: 113 (Cladophorus). E Africa

(Kilimanjaro). Described as a variation of C. notabilis

(Fåhraeus, 1851).

madecassus Pic, 1923: 13. Madagascar.

= gracilicornis Pic, 1922: 20 (homonym)

marshalli Kleine, 1933: 6 (Cladophorus). S Africa (Natal).

melanopterix Kleine, 1926: 124. E Africa (Usambara).

minimus Pic, 1928: 54. Cameroon.

minutus Pic, 1922: 19. Madagascar.

mocquerysi Pic, 1931: 107. Gabon.

montanus Kleine, 1933: 9 (Procautires). Uganda.

nanus Kleine, 1933: 7 (Cladophorus). Cameroon.

natalensis Bourgeois, 1902: 744 (Cladophorus). S Africa

(Natal).

nigerorum Kazantsev, 2012, nom.n. Zaire.

= africanus Dudkova et Bocakova, 2010: 46 (homo-

nym), RN for reticulatus Kleine, 1930: 9 (homonym)

nigricollis Kleine, 1935: 426. E Africa (Usambara).

nigricolor Pic, 1922: 20. Madagascar.

nigricornis Pic, 1928: 53 (Cladophorus). Uganda.

nigrithorax Pic, 1928: 53 (Cladophorus). S Africa (Natal).

nigrocarinatus Pic, 1922: 18. Gabon.

nigronotatus Kleine, 1926: 130. Uganda.

notabilis Fåhraeus, 1851: 437. (Calopteron). S Africa (Natal). notaticeps Pic, 1928: 53 (Cladophorus). Gabon.

nyassicus Kleine, 1933: 7 (Cladophorus). E Africa (Nyassa Lake). obconicus Pic, 1922: 20. Madagascar. obscurithorax Pic, 1931: 107. Zaire. obtusatus Bourgeois, 1902: 745. Madagascar. ochraceipennis Kleine, 1930: 6. Zaire. ocularis Bourgeois, 1882: ci. W Africa. opacicollis Kleine, 1930: 5. Zaire. pallens Kleine, 1926: 139. Cameroon. particularithorax Pic, 1925: 185 (Cladophorus). E Africa (Kilimanjaro). pentagonus Kleine, 1926: 139. S Africa (Natal). pilosus Kleine, 1935: 428 (Procautires). Zaire. politus Kleine, 1935: 426. Zaire.

pouilloni Pic, 1922: 19. Madagascar. prescutellaris Pic, 1928: 200 (Cladophorus). Uganda. profanus Kleine, 1943: 150. E Africa (Kilimanjaro). pusillus Kleine, 1926: 133. Cameroon.

reductocostatus Kazantsev, 2012, nom.n. Uganda.

= reductus Pic, 1928: 199 (Cladophorus) (homonym)

reductus Pic, 1922: 19. Madagascar.

reflexicollis Fairmaire, 1887: 57. Madagascar.

ribottii Pic, 1926: 127 (Cladophorus). Zaire

richardi Kazantsev, 2012, nom.n. Zaire.

= kleinei Bocák et Bocáková, 1988: 85 (homonym), RN for certus Kleine, 1930: 9 (homonym) rivalis Kleine, 1935: 429 (Procautires). Zaire. robustithorax Kleine, 1926: 121. Uganda. robustus Pic, 1931: 106. Cameroon. rufus Fairmaire, 1896: 347. N Madagascar (Mayotte). ruwenzoriensis Kleine, 1935: 427. E Africa (Ruwenzori). salubris Kleine, 1940: 253. Zaire. schoutedeni Kleine, 1930: 8. Zaire. scutellaris Pic, 1922: 19. Madagascar. septemareolatus Pic, 1950: 15. Madagascar. seydeli Kleine, 1930: 7. Zaire.

sibutensis Pic, 1922: 19. The Central African Republic ("Fort Sibut").

sikorai Pic, 1922: 19. Madagascar. similis Kleine, 1926: 137. Cameroon. sublineatus Pic, 1922: 19. Madagascar. subnitidus Pic, 1922: 20. Madagascar. subparallelus Pic, 1932: 23 (Procautires). Zaire. subrecticollis Pic, 1922: 20. Madagascar. sulcicollis J. Thomson, 1858: 78 (Lycus). Tropical Africa. taeniatus Bourgeois, 1902: 744 (Cladophorus). Madagascar.

tananarivanus Pic, 1922: 20. Madagascar. tanganensis Pic, 1922: 18. E Africa.

testaceicolor Pic, 1926: 119 (Cladophorus). Bioko Is. (Fernando Poo).

theresae Pic, 1928: 200 (Cladophorus). Uganda. torquatus Klug, 1833: 157. Madagascar. triangulus Kazantsev, 2012, nom.n. Zaire.

= triangularis Kleine, 1930: 6 (homonym)

tricarinatus Pic, 1950: 15. Madagascar.

trimaculatus Pic, 1922: 18. Cameroon. trinotatus Pic, 1922: 19. Madagascar. ugandanus Kleine, 1926: 122. Uganda. uniareolatus Pic, 1953: 4. Madagascar. unicolor Bourgeois, 1889: 242. Cameroon. usambarae Bourgeois, 1910: 114. E Africa (Usambara). wittmeri Pic, 1950: 15. Madagascar.

Genus Paracautires Kazantsev, 2012, gen.n.

type species Paracautires afra Kazantsev, 2012, sp.n. afra Kazantsev, 2012, sp.n. Bioko Is. (Fernando Poo), Cameroon. 
Genus Spartoires Kazantsev, 2012, gen.n.

type species Spartoires murzini Kazantsev, 2012, sp.n. murzini Kazantsev, 2012, sp.n. Congo.

Genus Tricautires Kazantsev, 2006: 219

type species Tricautires isabelae Kazantsev, 2006 isabelae Kazantsev, 2006: 223. Bioko Is. (Fernando Poo). tabounensis Kazantsev, 2012, sp.n. Guinea, Zaire.

Genus Xylobanus Waterhouse, 1879: 38

type species Lycus costifer Walker, 1858 alluaudi Bourgeois, 1902: 748. Madagascar. ambrensis Pic, 1922: 14. Madagascar. anceyi Pic, 1928: 61. Ghana ("Aschanti"). angustatus Pic, 1922: 14. Madagascar. arcuatithorax Pic, 1922: 14. Madagascar. atricolor Pic, 1922: 14. Madagascar. atricornis Pic, 1922: 14. The Central African Republic ("Fort Sibut"). atrimembris Pic, 1922: 16. E Africa (Nyassa Lake). burgeoni Kleine, 1937: 113. Zaire. camerunus Kleine, 1930: 175. W Africa. chappiusi Kleine, 1937: 113. E Africa. congoanus Pic, 1933: 110. Zaire. conicus Pic, 1922: 14. Madagascar. destrictus Kleine, 1927: 68. Madagascar. devotus Kleine, 1927: 58. E Africa. difficilis Kleine, 1927: 72. Uganda. diffusus Kleine, 1933: 20. Uganda. = differens Kleine, 1927: 68 (homonym) diversithorax Pic, 1925: 5. Uganda. Described as a variation of $X$. kisibanus Pic, 1922. donckieri Pic, 1922: 14. Zaire. feai Pic, 1924: 164. W Africa ("Port. Guinea"). fratellus Bourgeois, 1902: 749. Madagascar. fuscatus Bourgeois, 1900: 146. Ghana (“Aschanti”). inapicalis Pic, 1928: 50. Uganda. ivoirensis Pic, 1947: 8. Cote d'Ivoire. kisibanus Pic, 1922: 14. E Africa.

leonensis Pic, 1922: 14. Sierra Leone. longipennis Pic, 1931: 106. Zaire.

mauricei Kazantsev, 2012, nom.n. Madagascar.

= diversithorax Pic, 1953: 4 (homonym)

mocquerysi Pic, 1922: 14. Gabon.

nigricollis Bourgeois, 1910: 116. E Africa (Meru, Kilimanjaro). nigripes Bourgeois, 1910: 115. E Africa (Meru). Described

as a variation of $X$. semiflabellatus (Thomson, 1858). pallidicolor Kleine, 1930: 174. Cameroon. patrizii Pic, 1928: 128. E Africa. pentagonus Bourgeois, 1889: 245. W Africa. pluto Bourgeois, 1908: 503. Madagascar. semiflabellatus J. Thomson, 1858: 79 (Lycus). Gabon.

= sulcicollis Murray, 1868: 91 (Metriorrhynchus) (homonym)

sibutensis Pic, 1922: 14. The Central African Republic ("Fort Sibut").

solodovnikovi Kazantsev, 2012, sp.n. Uganda. tananarivanus Pic, 1922: 14. Madagascar. ugandanus Kleine, 1930: 174. Uganda. uluguriensis Kazantsev, 2012, sp.n. Uganda. uniareolatus Pic, 1953: 3. Madagascar. usambaraensis Kazantsev, 2012, sp.n. Uganda. vicinus Pic, 1928: 50. Uganda.

voeltzkowi Bourgeois, 1908: 502. Madagascar. xanthomerus Bourgeois, 1889: 245. Madagascar.
ACKNOWLEDGEMENTS. I wish to express my gratitude to Dr. P. Grootaert (Institut Royal de Sciences naturelles de Belgique, Bruxelles) and Dr. A. Solodovnikov (Zoological Museum of Copenhagen University) for enabling me to study the Lycidae collections under their care. My sincere thanks are also due to Dr. S. Murzin (Moscow) for the interesting additional material from Africa.

\section{References}

Bocák L. 2002. Generic revision and phylogenetic analysis of the Metriorrhynchinae (Coleoptera: Lycidae)// European Journal of Entomology. Vol.99. P.315-351.

Bocáková M. \& Bocák L. 2007. Lycidae. [P.211-224] // Löbl I. \& Smetana A. (eds.). Catalogue of Palaearctic Coleoptera. Vol.4. Stenstrup: Apollo Books. 935 p.

Bourgeois J. 1882. Deux notes relatives á différentes espèces de Lycides // Annales de la Société entomologique de France. T.2 (6é ${ }^{\mathrm{e}}$ série). P.100-102.

Bourgeois J. 1889. Voyage de M. Ch. Alluaud dans le territoire d'Assinie (Afrique occidentale) en juillet et août 1886. $1^{\text {re }}$ Mémoire // Annales de la Société entomologique de France. T.58. P.237-246.

Bourgeois J. 1897. Description de Malacodermes nouveaux recueillis en Océanie par M. le Dr. Ph. François // Bulletin de la Société entomologique de France. T.66. P.72-74.

Bourgeois J. 1900. Etude sur les Lycides du Musée Royal d'Histoire Naturelle de Belgique (espèces du Congo et pays voisins)// Annales de la Société entomologique de Belgique. T.44. P.139-146.

Bourgeois J. 1902. Diagnoses de Lycides nouveaux ou peu connus. $8^{\mathrm{e}}$ partie // Annales de la Société entomologique de France. T.71. P.735-750.

Bourgeois J. 1905. Malacodermes de la Guinée Espagnole // Memorias de la Sociedad espanola de Historia natural. T.1. P.189-196.

Bourgeois J. 1908. Diagnoses de Lycides nouveaux ou peu connus. $9^{\mathrm{e}}$ partie // Annales de la Société entomologique de France. T.77. P.501-504.

Bourgeois J. 1910. 10. Malacodermata // Wissenschaftliche Ergebnisse der Schwedischen Zoologischen Expedition nach dem Kilimandjaro, dem Meru und den umgebenden Massaisteppen, Deutsch-Ostafrikas, 1905-1906, unter Leitung von Prof. Dr. Yngve Sjøstedt. 7. Coleoptera. Stockholm: P. Palmquists. P.105138. Taf.3.

Dudkova P. \& Bocák L. 2010. A review of Cautires obsoletus species group from Indo-Burma (Coleoptera, Lycidae) // Zootaxa. Vol.2527. P.28-48.

Fåhraeus C.H. 1851. In: Boheman C.H. Insecta Caffrariae annis 1838-1845 J.A. Wahlberg collecta, amici auxilio suffutus. Pars I. Fasc. II. Holmiae [=Stockholm]: Norstedt. P.299-626.

Fairmaire L. 1869. Notes sur les Coléoptères recueillis par Charles Coquerel á Madagascar et sur les côtes d'Afrique. $2^{\mathrm{e}}$ partie // Annales de la Société entomologique de France. T.9 (4e série). P.179-260.

Fairmaire L. 1880. Description de quelques Coléoptères de Nossi-Bé // Annales de la Société entomologique de France T.10 (5e série). P.321-340.

Fairmaire L. 1884. Note sur les Coléoptères recueillis par M. Ach. Raffray à Madagascar et descriptions des espèces nouvelles $\left(1^{\text {re }}\right.$ P.) // Annales de la Société entomologique de France. T.4 (6 série). P.229-234.

Fairmaire L. 1887a. Coléoptères des voyages de M. G. Revoil chez les Somalis et dans l'Intérieur du Zanquebar // Annales de la Société entomologique de France. T.6 (6 $6^{\mathrm{e}}$ série). P.69-186, 277368, pl.1-3.

Fairmaire L. 1887b. Diagnoses de Coléoptères nouveaux de Madagascar // Le Naturaliste. T.9. P.56-57.

Fairmaire L. 1896. Matériaux pour la faune coléoptérique de la région malgache // Annales de la Société entomologique de Belgique. T.40. P.336-398.

Fairmaire L. 1901. Matériaux pour la faune coléoptérique de la région malgache ( $11^{\mathrm{e}}$ note) // Revue d'Entomologie. T.20. P.101-248 
Gerstaecker A. 1871. Beitrag zur Insectenfauna von Zanzibar III. Coleoptera // Archiv für Naturgeschichte. Bd.37. S.4286.

Kazantsev S.V. 2000. New lycids from China (Coleoptera, Lycidae) // Miscellania Zoologica. Vol.23. No.2. P.79-92.

Kazantsev S.V. 2002. New and little known species of Lycidae (Coleoptera) from China // Russian Entomological Journal. Vol.11. No.3. P.253-263.

Kazantsev S.V. 2006a. A new African genus of Metriorrhynchini (Coleoptera: Lycidae) // Zoosystematica Rossica. Vol.14. P.219 221.

Kazantsev S.V. 2006b. New taxa of net-winged beetles $(\mathrm{Co}-$ leoptera, Lycidae) from Sri Lanka // Eurasian Entomological Journal. Vol.5. No.2. P.127-131 (in Russian).

Kazantsev S.V. 2007. Marena gen.n., new Metriorrhynchini genus from New Guinea (Coleoptera: Lycidae) // Russian Entomological Journal. Vol.16. No.3. P.297-300.

Kazantsev S.V. 2010. New taxa of Papuan net-winged beetles (Lycidae, Coleoptera) // Latvijas Entomologs. Vol.48. P.92100

Kleine R. 1926. Bestimmungstabelle der Gattung Cautires C.O.Waterhouse // Archiv für Naturgeschichte. Ser.A. Bd.92. S.118-144.

Kleine R. 1927. Bestimmungstabelle der Gattung Xylobanus C.O.Waterhouse // Tijdschrift voor Entomologie. Bd.70. S.43-72.

Kleine R. 1930a. Die Cautires-Arten des Congo-Museums nebst Bestimmungsschlussel der afrikanischen Arten // Revue de Zoologie et de Botanique Africaines. T.19. P.4-19.

Kleine R. 1930b. Studien zur Gattung Bulenides C. O. Wtrh. // Treubia. Bd.11. H.3. S.349-355.

Kleine R. 1930c. Neue Xylobanus-Arten aus Westafrika nebst Fundnotizen // Revue de Zoologie et de Botanique Africaines. T.19. P.172-176.

Kleine R. 1933a. Pars 123: Lycidae // Coleopterorum Catalogus auspiciis et auxilio W. Junk editus a Schenkling. Berlin: W. Junk. 145 p.

Kleine R. 1933b. Neue Lyciden und Bemerkungen zum Cat. Col Junk-Schenkling Lycidae // Stettiner Entomologische Zeitung. Bd.94. H.1. S.1-20.

Kleine R. 1935. Neue Lyciden aus Afrika // Revue de Zoologie et de Botanique Africaines. T.26. P.425-429.

Kleine R. 1937. Les Lycides du Congo Belge // Annales du Musée du Congo Belge. Ser.3. T.2. No.6. P.61-120.

Kleine R. 1940. Neue Brenthiden und Lyciden aus dem CongoMuseum // Revue de Zoologie et de Botanique Africaines. T.33. P.245-255.

Kleine R. 1942. Brenthidae und Lycidae (Addendum) // Expl. Parc National Albert, I. Mission G.F. de Witte 1933-1935. T.8. P. 1-9.
Kleine R. 1943. Neue Lyciden aus dem Ungarischen NationalMuseum (Coleopt.) // Annales Historico-Naturales Musei Nationalis Hungarici (Pars Zoologica). T.36. P.145-156.

Miller R.S. 2002. Family 59. Lycidae Laporte, 1838 // Arnett R.H., Jr., Thomas M.C., Skelley P.E. \& Frank J.H. (eds.). American Beetles. Vol.2. Polyphaga through Curculionoidea. Boca Raton, FL: CRC Press. P.174-178

Murray A. 1868. List of Coleoptera received from Old Calabar, on the West Coast of Africa // The Annals and Magazine of Natural History, including Zoology, Botany and Geology (series 4). Vol.2. P.91-111, P1. VIII.

Pic M. 1921-1922. Contribution à l'étude des Lycides // L'Echange, hors texte. Vol.37-38. P.1-28.

Pic M. 1922. Nouveautés diverses // Mélanges exotico-entomologiques. T.35. P.1-32.

Pic. M. 1924. Lycides africains nouveaux // Annali del Museo Civico di Storia Naturale di Genova. T.51. P.161-164.

Pic M. 1924-1939. Malacodermes exotiques // L'Echange, hors texte. Vol.40-55. P.1-472.

Pic M. 1925a. Diagnoses préliminaires de Lycides africains [Col.] // Bulletin du Muséum d'Histoire Naturelle. P.184-187.

Pic. M. 1925b. Zoological results of the Swedish Expedition to Central Africa 1921. Insecta. 8. Anobiidae et Malacodermes // Arkiv för Zoologi. Ser.A. Bd.17. H.5. S.1-9.

Pic M. 1928a. Diagnose d'un nouveau Lycide africain [Col.] // Bulletin de la Société entomologique de France. P.112.

Pic M. 1928b. Note sur les Cladophorus [Col., Lycidae] // Bulletin de la Société entomologique de France. P.199-200.

Pic. M. 1928c. Etudes sur les Lycides // Annali del Museo Civico di Storia Naturale di Genova. T.52. P.116-129.

Pic M. 1928d. Pour aider á l'étude du genre Xylobanus Wat. (Col.) // Bulletin de la Société zoologique de France. T.53. P.46-50.

Pic. M. 1931. Neue exotische Coleopteren (Malacodermata) // Entomologischer Anzeiger. Bd.11. S.377-379.

Pic M. 1947. Coléoptères du Globe // L'Echange. T.63. P.1-16. Pic M. 1950. Coléoptères du Globe // L'Echange. T.66. P.1-16. Pic M. 1953. Coléoptères du Globe // L'Echange. T.69. P.2-4. Thomson J. 1858. Voyage au Gabon. Histoire naturelle des Insectes et des Arachnides recueillis pendant un voyage fait au Gabon en 1856 et en 1857 par M. Henry C. Deyrolle sous les auspices de MM. Le Conte de Mnizech et James Thomson précédée de l'histoire de voyage. Deuxième Partie. Insectes. I. Ordre Coléoptères. Famille XVII. Lampyridae // Archives entomologiques ou recueil contenant des illustrations d'Insects nouveaux ou rares. T.2. P.76-79.

Waterhouse C.O. 1879. Illustrations of Typical Specimens in the Collection of the British Museum. Part 1 - Lycidae. London: Taylor and Francis. 93 p. 